\title{
Article \\ Molecular Impacts of Dietary Exposure to Nanoplastics Combined or Not with Arsenic in the Caribbean Mangrove Oysters (Isognomon alatus)
}

\author{
Marc Lebordais ${ }^{1,2}$, Zélie Venel ${ }^{1}$, Julien Gigault ${ }^{3}{ }^{\mathbb{D}}$, Valerie S. Langlois ${ }^{2}$ and Magalie Baudrimont ${ }^{1, *}$ \\ 1 Université de Bordeaux, CNRS, UMR EPOC 5805, Place du Dr Peyneau, 33120 Arcachon, France; \\ Marc.Lebordais@ete.inrs.ca (M.L.); zelie.venel@gmail.com (Z.V.) \\ 2 Centre Eau Terre Environnement, Institut National de la Recherche Scientifique (INRS), \\ 490 rue de la Couronne, Québec City, QC G1K 9A9, Canada; Valerie.Langlois@inrs.ca \\ 3 Université Laval, UMI Takuvik 3376, 1045 Avenue de la Médecine, Québec City, QC G1V 0A6, Canada; \\ julien.gigault@takuvik.ulaval.ca \\ * Correspondence: magalie.baudrimont@u-bordeaux.fr; Tel.: +33-(0)-5-5622-3927
}

Citation: Lebordais, M.; Venel, Z.; Gigault, J.; Langlois, V.S.; Baudrimont, M. Molecular Impacts of Dietary Exposure to Nanoplastics Combined or Not with Arsenic in the Caribbean Mangrove Oysters (Isognomon alatus). Nanomaterials 2021, 11, 1151. https:// doi.org/10.3390/nano11051151

Academic Editor: Laura Canesi

Received: 19 March 2021

Accepted: 22 April 2021

Published: 28 April 2021

Publisher's Note: MDPI stays neutral with regard to jurisdictional claims in published maps and institutional affiliations.

Copyright: (C) 2021 by the authors. Licensee MDPI, Basel, Switzerland. This article is an open access article distributed under the terms and conditions of the Creative Commons Attribution (CC BY) license (https:// creativecommons.org/licenses/by/ $4.0 /)$.

\begin{abstract}
Nanoplastics (NPs) are anthropogenic contaminants that raise concern, as they cross biological barriers. Metals' adsorption on NPs' surface also carries ecotoxicological risks to aquatic organisms. This study focuses on the impacts of three distinct NPs on the Caribbean oyster Isognomon alatus through dietary exposure. As such, marine microalgae Tisochrysis lutea were exposed to environmentally weathered mixed NPs from Guadeloupe (NPG), crushed pristine polystyrene nanoparticles (PSC), and carboxylated polystyrene nanoparticles of latex (PSL). Oysters were fed with NP-T. lutea at 10 and $100 \mu \mathrm{g} \mathrm{L}^{-1}$, concentrations considered environmentally relevant, combined or not with $1 \mathrm{mg} \mathrm{L}^{-1}$ pentoxide arsenic (As) in water. We investigated key gene expression in I. alatus' gills and visceral mass. NP treatments revealed significant induction of cat and sod1 in gills and gapdh and sod1 in visceral mass. As treatment significantly induced sod1 expression in gills, but once combined with any of the NPs at both concentrations, basal mRNA levels were observed. Similarly, PSL treatment at $100 \mu \mathrm{g} \mathrm{L}{ }^{-1}$ that significantly induced cat expression in gills or sod1 in visceral mass showed repressed mRNA levels when combined with As (reduction of $2222 \%$ and $34 \%$, respectively, compared to the control). This study suggested a protective effect of the interaction between NPs and As, possibly by decreasing both contaminants' surface reactivity.
\end{abstract}

Keywords: nanoplastics; bivalve; gene expression; trophic pathway; metal

\section{Introduction}

Plastic contamination is a worldwide environmental issue, as recognized by the United Nations Environment Program [1]. Daily used plastic products can last in the environment for several hundred years without being completely degraded [2,3]. With an average of 8 million tons of plastic waste discarded into oceans each year, Wright and Kelly (2017) estimated an accumulation of 250 million tons by 2025 [4]. Aquatic ecosystems act as natural receptacles for contaminants, including plastic debris, that are eventually carried by currents and converge to five main ocean areas called gyres [5]. Guadeloupe island is an example of a terrestrial area exposed to the North Atlantic gyre (seventh expedition continent in 2015, [6]). In the gyre, different sizes of plastic debris can be identified: large microplastics (size $<5 \mathrm{~mm}$; [7]), microplastics (size $<0.3 \mathrm{~mm}$; [8]), and nanoplastics (size $<0.001 \mathrm{~mm}$; [9]).

Nanoplastics (NPs) are commonly referred to as plastic nanoparticles smaller than $1000 \mathrm{~nm}$ in one of the three dimensions of space [10]. NPs originating from industrial synthesis are referred to as primary NPs, whereas those from environmental degradation are called secondary NPs [8,11]. Indeed, nanofragmentation of plastic occurs within 
aquatic ecosystems through physical abrasions and chemical oxidations (e.g., waves, salt, and mainly UV; $[12,13])$, thus yielding more available additives used for specific plastic properties (e.g., plasticizers, UV-filters, flame retardants, and metals; [4,9]). As plastic debris age and fraction into NPs, more polar surfaces are formed, allowing contaminants to desorb or be adsorbed onto NP surfaces $[4,14,15]$. For example, Davranche et al. (2019) recently documented metallic adsorption on marine NPs [16]. Further analyses revealed that arsenic was one of the most abundant metals adsorbed on the collected plastics from Guadeloupean beaches [17]. Therefore, since most marine species ingest plastic debris regularly $[18,19], \mathrm{NPs}^{\prime}$ potential toxicity triggered questioning. Indeed, NPs have high residence time, surface reactivity, and size availability for cellular uptake $[20,21]$ that present a great risk of interaction and bioaccumulation within organisms [22-24]. As such, nanoparticles have been classified as emerging contaminants [25]. However, there is a critical lack of data on NPs' fate and bioavailability, mostly explained by quantification challenges [26-28]. For example, due to higher ionic strength in seawaters, it causes NP aggregation [26-31]. Yet Gigault et al. (2018b) newly observed limited aggregation of NPs passing through a salinity gradient [12], thus making ecotoxicological NP studies all the more relevant in estuarine areas such as mangroves. As a matter of fact, mangroves hold a significant role in ecosystem services [32]; also, their sensitive functioning provides helpful indicators to study worldwide issues [33,34].

To tackle the impacts of ingested NPs, we studied NPs' effects alone and combined with arsenic (As) on Caribbean oysters. We conducted our experiment on Isognomon alatus wild oysters native to Guadeloupean mangrove swamps, since oysters are relevant organisms for ecotoxicological studies. Bivalves have indeed been commonly used as bioindicators for decades [35-37], particularly as monitoring organisms, given that they tolerate and accumulate high metal concentrations [32,38] and nanoparticles [39]. Additionally, plastic exposure of bivalve aquacultures recently raised concerns with regard to their putative role of NPs' transfer into the food web up to humans $[4,40,41]$. Trophic exposure is an under-rated NPs pathway [42-44] that we explored through NPs-contaminated phytoplankton used to feed I. alatus oysters. Indeed, filter-feeding bivalves rely on ciliated structures to collect phytoplankton but also organic and inorganic particles (up to $500 \mathrm{~nm} ;[45,46])$. Thus, to mimic the environmental feeding conditions of I. alatus, solutions of the marine microalgae Tisochrysis lutea were used to expose oysters to three different NPs. Selected NPs for this study encompassed a custom of mixed Guadeloupean NPs to represent the environmental plastic weathering (NPG; secondary NPs), the crushed pristine polystyrene nanoparticles (PSC, primary NPs; [47]), and the additives-free synthetic carboxylated polystyrene nanoparticles of latex (PSL; [48]). Most NP studies have used monodispersed calibrated nanospheres, but these spherical NPs have been considered poorly relevant to address ecotoxicology issues $[13,49]$. Therefore, in the present study, we aimed to investigate gene expression changes of I. alatus exposed by the dietary route to NPs $\left(10\right.$ and $100 \mu \mathrm{g} \mathrm{L}^{-1}$ ), in the presence or absence of As in the water. These NP concentrations are environmentally representative $[50,51]$ and belong to the lowest range of in-laboratory NP exposures [49]. Our set of genes was chosen in order to target NPs and/or As mechanisms of action on endocytosis, cell cycle regulation, oxidative stress, mitochondrial metabolism, and detoxification, as those cellular functions are known to be commonly affected by nanoparticles and/or metallic contaminants [39]. Considering the ecotoxicological relevance of NPG as a mix of polydispersed NPs (with heterogeneous shapes, specific surface area, and oxidative degree), we also investigated the NPG's putative role towards arsenic bioaccumulation into I. alatus gills and visceral mass. Overall, the main novelty of our study lies in comparing the effects of three relevant NPs, combined or not with arsenic, on I. alatus key genes. 


\section{Materials and Methods}

\subsection{Nanoplastic Dispersions}

Plastics used to generate the mixed nanoplastics from Guadeloupe (NPG) were collected in 2016 on the Guadeloupean beaches $\left(16^{\circ} 21^{\prime} 06^{\prime \prime} \mathrm{N} ; 61^{\circ} 23^{\prime} 09^{\prime \prime} \mathrm{W}\right)$, naturally aged in situ by environmental factors (salt, mechanical abrasion, and mainly UV exposure). Polystyrene pristine pellets used to produce crushed nanoparticles (PSC) were commercially purchased from Goodfellow (Lille, France). Both nanoplastic dispersions were prepared according to an optimized protocol [47]. Plastics pellets were degraded with $99 \%$ ethanol in a blade grinder to get a primary powder and later fragmented using a planetary ball mill [47]. The resultant powder was then dried by lyophilization to remove ethanol, then suspended in ultra-pure water and filtered on cellulose acetate filters $(5-6 \mu \mathrm{m}$ pore size; VWR, Biare, France). Hydrodynamic diameters of NPG and PSC nanoparticle dispersions of $50 \mathrm{ppm}$ (in total organic carbon) were measured by dynamic light scattering (DLS) (Table 1) through a contactless (in situ) DLS probe at $170{ }^{\circ} \mathrm{C}$ on a Vasco flex instrument (Cordouan Technologies ${ }^{\circledR}$, Pessac, France). The intensity fluctuations as a function of the time were processed as an autocorrelation function. The cumulants algorithm was used to fit this function in order to obtain a size distribution (z-average). The surface charges of particles (potential $\zeta$ ) were assessed using a Wallis zetameter (Cordouan Technologies ${ }^{\circledR}$, Pessac, France) (Table 1). Details of NPG and PSC dispersions are, respectively, presented in Supplementary Materials Figures S1 and S2. The carboxylated polystyrene nanoparticles of latex (PSL) were synthesized and calibrated by IPREM (Pau, France) with $43 \mathrm{COOH}$ groups per $\mathrm{nm}^{2}$ and a z-average of $390 \pm 20 \mathrm{~nm}$. Additionally, they were made spherical with a raspberry-like surface texture [48].

Table 1. Main characteristics of NP dispersions measured by DLS in situ on a Vasco Flex instrument (Cordouan Technologies ${ }^{\circledR}$, Pessac, France).

\begin{tabular}{ccc}
\hline Nanoparticles & Z-Average $(\mathbf{n m}) /$ PDI & Potential $\zeta(\mathbf{m V}) \mathbf{5} \mathbf{~ m M ~ N a C l , ~ p H ~ 7 ~}$ \\
\hline NPG & $361 \pm 40 \mathrm{~nm} / 0.210$ & $-30.2 \pm 1.1$ \\
PSC & $354 \pm 30 \mathrm{~nm} / 0.190$ & $-44.0 \pm 2.0$ \\
PSL & $390 \pm 20 \mathrm{~nm} / 0.002$ & $-42.0 \pm 2.0$ \\
\hline
\end{tabular}

Noteworthily, polystyrene was chosen for both PSL and PSC, as it is one of five main plastics produced, representing $90 \%$ of global demand [52]. All three nanoplastic particle sizes were suspended and diluted as needed in ultra-pure water $\left(18 \mathrm{M} \Omega \mathrm{cm}^{-1}\right.$, Millipore water purification system, Merck, Darmstadt, Germany) in cleaned glass vials. The mass concentration of each nanoplastic dispersion was measured by total organic carbon (TOC) analysis on a Shimadzu ${ }^{\circledR}$ instrument (Europa GmbH, Duisburg, Germany).

\subsection{Microalgae and Oyster Cultures}

The microalgae species used to feed the oysters during the acclimation period were Tisochrysis lutea [41,53] and Thalassiosira weissflogii [54] obtained from Lycée polyvalent de la Mer (Gujan-Mestras, France). Of note, T. weissflogii was only used during oyster acclimation for nutritional purposes [55]. Both algal cultures were cultivated into glass balloons in F/2 medium at salinity $26 \%$ and oxygenated by an air distribution pump through a glass pipette. As recommended by Helm and Bourne (2004) [56], the microalgae were grown at $22{ }^{\circ} \mathrm{C}$ under $24: 24$ artificial light of $100 \mu \mathrm{mol} / \mathrm{m}^{2} / \mathrm{s}$.

This study used native tropical flat oysters, as they are representative of mangrove swamps [57,58]. Individuals of I. alatus were collected from their natural habitat in Grand Cul-de-sac Marin ( $\left.16^{\circ} 18^{\prime} 58.1460^{\prime \prime} \mathrm{N} ; 61^{\circ} 32^{\prime} 1.9379^{\prime \prime} \mathrm{O}\right)$, a natural reserve to the north of Pointe-à-Pitre in Guadeloupe. Once brought to the laboratory, they were individually brushed to remove external parasites and stored in $30 \mathrm{~L}$ tanks ( 100 oysters per tank) lined with tiles to fulfill I. alatus' need for a hanging substrate. The tanks were filled with reconstituted seawater (Instant Ocean ${ }^{\circledR}$ ) at 32\% salinity, oxygenated, and filtered by an 
aquarium filter pump. Additionally, 2/3 of the water tanks were renewed every two days during the first week of oysters' acclimation given their high organic matter release. Similar to I. alatus native environmental conditions, they were acclimatized at $26{ }^{\circ} \mathrm{C}$ with aquarium heaters and under 12:12 (natural light: dark cycles) for 15 days according to A. Arini (personal communication, 2 February 2019). Oysters were fed twice a week with $100 \mathrm{~mL}$ of mixed T. lutea and T. weissiflogii $\left(10 \times 10^{6}\right.$ cells L $^{-1}$ and $2 \times 10^{6}$ cells $\mathrm{L}^{-1}$, respectively) per tank.

\subsection{Experimental Design of Trophic Exposure}

A preliminary experiment was conducted to determine T. lutea optimal exposure to NP solutions (Figure 1). Tisochrysis lutea solutions were exposed in $10 \mathrm{~mL}$ individual glass vials with five replicates. Of note, all the glassware exposed to NPs was previously cleaned using an acid bath of 3\% nitric acid, rinsed with distilled water, then with $70 \%$ ethanol, and dried under a fume hood. Cell concentrations were measured daily for $96 \mathrm{~h}$ by spectrophotometry at $750 \mathrm{~nm}$. Based on microalgae concentration variability, we estimated that $48 \mathrm{~h}$ was the optimal duration to conduct the trophic exposure. Thus, NPG, PSC, and PSL were separately added into algal solutions for $48 \mathrm{~h}$ at low nominal concentrations of 10 and $100 \mu \mathrm{g} \mathrm{L}{ }^{-1}$ reported to be relevant proxies of NPs' environmental concentration [50,51]. Prior to each NP inoculation, the microalgae concentrations were controlled by counting on a Nageotte chamber and brought to $1 \times 10^{6}$ cells $\mathrm{mL}^{-1}$. Each NP-T. lutea solution was exposed to similar abiotic conditions (media, temperature, light) as the acclimation phase previously mentioned. To avoid NP accumulation onto the air pump tubing, the NP-T. lutea solutions were oxygenated through an agitation table [6].
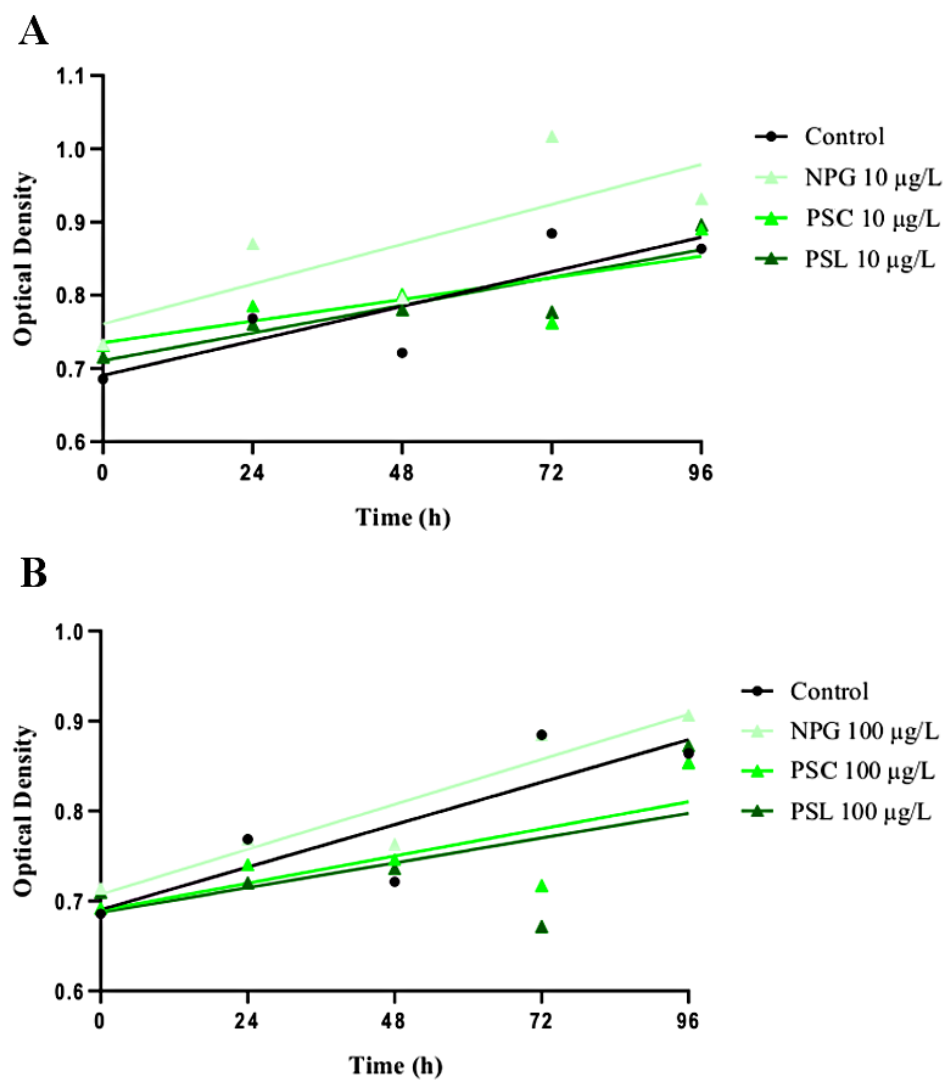

Figure 1. Tisochrysis lutea growth cultured in F/2 medium for $96 \mathrm{~h}$. Linear regressions with mean points $(n=5)$ are represented for $10 \mu \mathrm{g} \mathrm{L}^{-1} \mathrm{NP}$ treatments (A) and $100 \mu \mathrm{g} \mathrm{L}^{-1} \mathrm{NP}$ treatments (B). Regression coefficients (A) are control $=0.74, \mathrm{NPG}=0.60, \mathrm{PSC}=0.61, \mathrm{PSL}=0.80$. Regression coefficients $(\mathbf{B})$ are control $=0.74, \mathrm{NPG}=0.90, \mathrm{PSC}=0.59, \mathrm{PSL}=0.33$. 
A single solution of dissolved pentoxide arsenic (hereafter referred to As) was used (Merck KGaA ${ }^{\circledR}$, Darmstadt, Germany). Among inorganic forms of arsenic, pentoxide arsenic has been chosen, as it is the most abundant form found in oxygenated marine waters [59-62]. Oyster exposure to $1 \mathrm{mg} \mathrm{L}^{-1}$ As was conducted through batch injection at the beginning of the exposure (day 0 ). This As nominal concentration was based on oyster bioaccumulation tolerance and As levels in seawater [63-65]. To keep the concentration consistent at $1 \mathrm{mg} \mathrm{L}^{-1}$ throughout the exposure, water samples were collected in the morning and As levels were quantified. Thus, As concentration was adjusted one day out of two if needed.

The experimental design encompassed (Figure 2) a control of reconstituted seawater, an As treatment of $1 \mathrm{mg} \mathrm{L}^{-1}$, three single-NP treatments (NPG, PSC, and PSL) at 10 and $100 \mu \mathrm{g} \mathrm{L}^{-1}$, and a mix of As $\left(1 \mathrm{mg} \mathrm{L}^{-1}\right)$ with each of the NP treatments (As $+10 \mu \mathrm{g} \mathrm{L}^{-1} \mathrm{NP}$ and As $\left.+100 \mu \mathrm{g} \mathrm{L}{ }^{-1} \mathrm{NP}\right)$. All treatments were run in quadruplicate with two oysters per $500 \mathrm{~mL}$ glass jar.

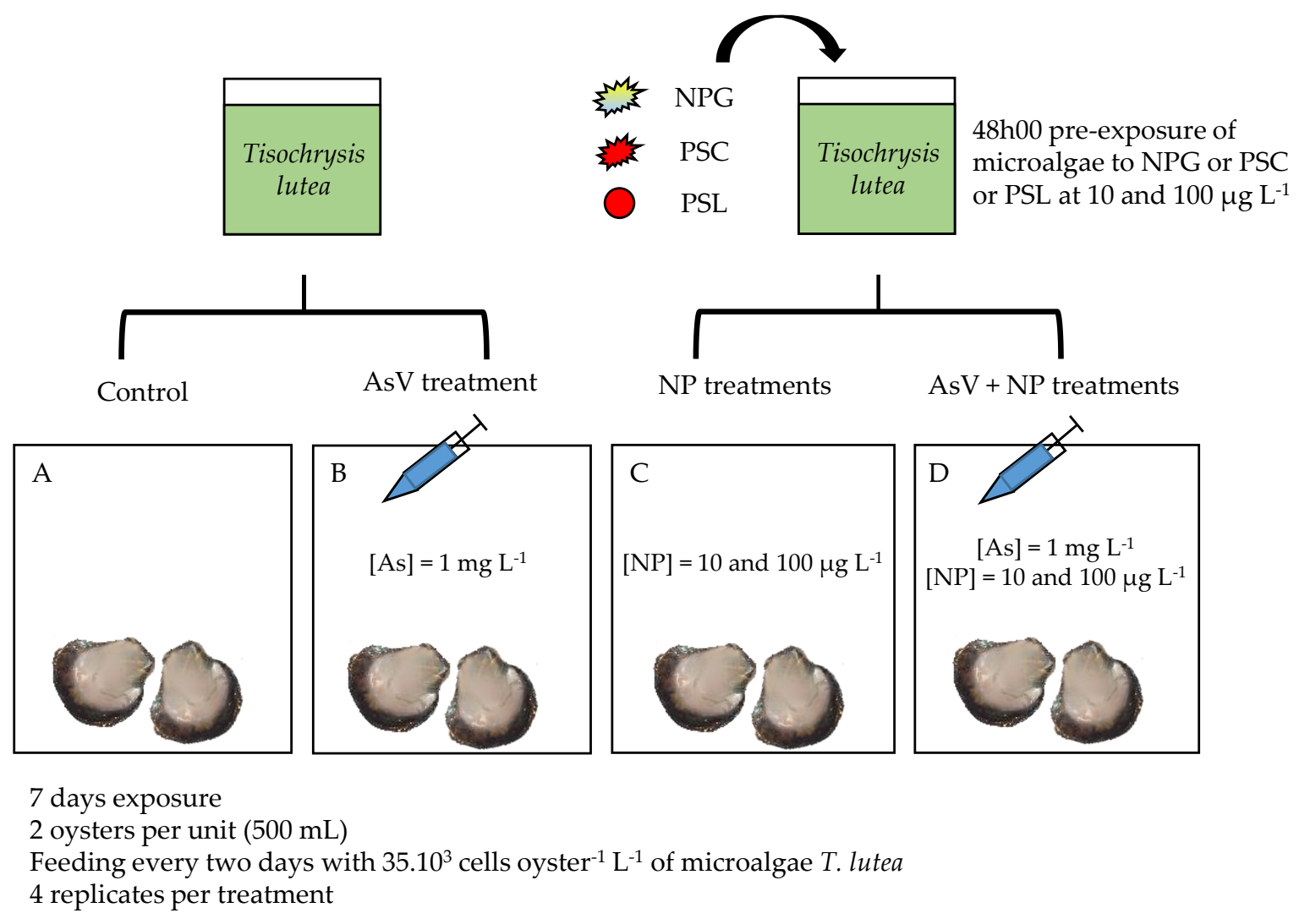

Figure 2. Experimental procedure of I. alatus trophic exposure. Condition (A) corresponds to control. Arsenic injections were performed at day 0 in treatments $(\mathbf{B}, \mathbf{D})$. NPs were added through pre-exposed microalgae feeding, one day out of two in treatments (C,D). NP refers to individual NPG, PSC, or PSL treatments.

Each jar was parafilm-covered to minimize evaporative loss. Water oxygenation was ensured by an air distribution pump. The oysters were under the same abiotic conditions (salinity, temperature, and light) as the above-mentioned acclimation period. Oysters of each condition were fed every two days with $35 \times 10^{3}$ cells oyster $^{-1} \mathrm{~L}^{-1}$ microalgae considered as a relevant environmental concentration [66]. After one week of dietary exposure, individual oysters were assessed for biometric parameters (Supplementary file (S); Supplementary Materials Figure S3). Each tissue was manually dried with paper, then weighed (fresh weight). Gills and visceral mass were sampled for arsenic bioaccumulation 
and molecular assays. Empty shells were also individually measured and weighed. Thus, the condition index [67] was calculated as follows in Equation.

$$
\mathrm{CI}=\frac{\text { leftover tissues } * \text { weight }}{\text { shells weight }} \times 100
$$

$*$ leftover tissues : whole body excluding gills and visceral mass

\subsection{Water and Tissue Arsenic Quantification by ICP-OES}

To evaluate the efficiency of the As dissolution and dilution, a nominal solution of $1 \mathrm{mg} \mathrm{L}^{-1}$ was prepared from a $1 \mathrm{~g} \mathrm{~L}^{-1}$ As solution. The $1 \mathrm{mg} \mathrm{L}^{-1}$ solution was then acidified with $3 \%$ nitric acid to measure the final concentration on an inductively coupled plasma optical emission spectrometry (ICP-OES 700 series, Agilent, Santa Clara, CA, USA). To monitor and compensate for the As concentration throughout the exposure week, water samples of $0.5 \mathrm{~mL}$ were collected per jar and acidified at 3\% nitric acid for ICP-OES analysis.

For tissue analyses, the pooled gills and visceral mass were dried $\left(48 \mathrm{~h}\right.$ at $\left.50{ }^{\circ} \mathrm{C}\right)$ and weighted prior to digestion (dry weight). Tissue samples were then acidified with $70 \%$ nitric acid ( $3 \mathrm{~mL}$ per sample) and heated at $100{ }^{\circ} \mathrm{C}$ for $3 \mathrm{~h}$ on a hot plate (Digiprep, SCPScience, Québec, Canada). After dilution of the digestates with $18 \mathrm{~mL}$ of pure water, total As bioaccumulation was measured using an ICP-OES (Figure 3). Certified biological reference materials (dolt-5, [68]) were systematically analyzed with the samples to ensure that the data obtained were within the certified range.

A

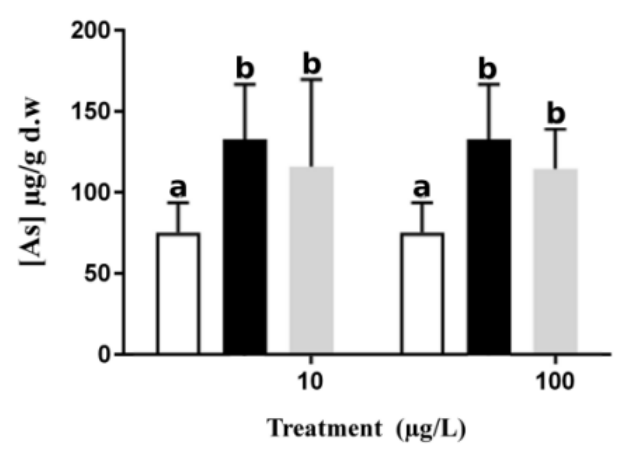

B

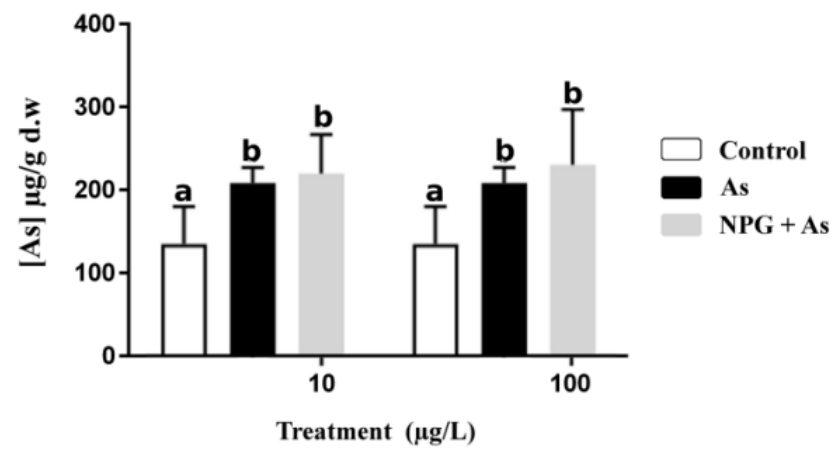

Figure 3. Arsenic accumulation in gills (A) and visceral mass (B) $\left(\mu \mathrm{g} \mathrm{g}^{-1}\right.$ dry weight, mean $\left.+\mathrm{sd}\right)$, after one week of exposure to 0 (Control) and $1 \mathrm{mg} \mathrm{L}^{-1}$ of As alone or combined with NPG (10 and $\left.100 \mu \mathrm{g} \mathrm{L}^{-1}\right)$. Different letters denote statistical differences between treatments assessed by two-way ANOVA followed by Bonferonni post-hoc test $(n=4) ; p<0.05$.

\subsection{RNA Extraction and cDNA Synthesis}

Gill and visceral mass tissues were preserved in RNA later at $-20{ }^{\circ} \mathrm{C}$ right after dissections. For minimal weight purposes, tissues from two oysters were pooled together. Tissues were ground with a Biorad Fastprep ${ }^{\circledR}(40 \mathrm{~s}$ at 6 movements/s) in $500 \mu \mathrm{L}$ of RNA lysis buffer, using ceramic pellets (Lysing Matrix D Bulk from MP Biomedicals). Deproteinization was done by adding $500 \mu \mathrm{L}$ of phenol-chloroform isoamyl alcohol, as this organic solvent is very suitable for oyster tissues rich in proteins and fat [69]. Then, samples were vortexed and centrifuged for $5 \mathrm{~min}$ at $9000 \times g$ to separate the organic and the aqueous phases. From there, total RNA was extracted using the Promega kit "SV Total RNA Isolation System" according to the manufacturer. Extracted RNA concentration was measured by using a microplate spectrophotometer at $260 \mathrm{~nm}$, and RNA quality was estimated with a Take3 plate (nucleic acids purity ensured by $260 / 280$ ratio $\geq 2$ ), both from BioTek EPOCH ${ }^{\circledR}$. All samples were diluted to obtain the same RNA concentration (1000 ng in $10 \mu \mathrm{L}$ ) before performing reverse transcription to synthesize complementary 
DNA (cDNA) with the Promega kit "GoScript Reverse Transcription System" according to the supplier's instructions.

Given the non-sequenced genome of I. alatus, genes of interest were selected from the reconstituted I. alatus transcriptome sequenced by Lemer (2019) [70]. For each gene, specific primer sets were designed using Primer3Plus. The primer details can be found in Supplementary Materials Table S1. Our genes of interest were representative of five biological functions. Transport-pathway-related genes included cav (cell membrane invagination for endocytosis) and cltc (intracellular vesicle transport; [71,72]). Genes related to cell cycle regulation included p53 (tumor suppressor; [73]), gadd45 (DNA repair; [74]), and bax (apoptotic activator; [73]). Oxidative stress-related genes included sod1 (dismutation of superoxides into $\mathrm{O}_{2}$ and $\mathrm{H}_{2} \mathrm{O}_{2}$ ), cat (conversion of $\mathrm{H}_{2} \mathrm{O}_{2}$ into $\mathrm{O}_{2}$ and $\mathrm{H}_{2} \mathrm{O}$; [75]), and gapdh (reduction and oxidation activities; [76,77]). Mitochondrial metabolism-related genes included cox 1 (respiratory chain electron transport), normalized by $12 S$ being indicative of the ribosomic RNA level [78,79], and detoxification related genes included $m d r$ (drugs' cell expulsion; [80]).

\section{6. $q P C R$ Assays and Validations}

A real-time quantitative polymerase chain reaction (qPCR) was performed with the Promega kit "GoTaq ${ }^{\circledR}$ qPCR Master Mix" containing the $5 \times$ buffer, the Taq polymerase, $\mathrm{MgCl}_{2}$, dNTP, and SybrGreen dye. Validation of the primer's efficiency and specificity was conducted so that $1 \mu \mathrm{L}$ of the forward and reverse primers (100 $\mu \mathrm{M}$ each) was optimal for conducting the reactions. Together with the qPCR mix, primers were added to $1 / 10$ diluted cDNA. The resulting final volume was poured into white 96-well qPCR plates, including two no-template control wells without cDNA, and replaced by RNAse free-water. Plates were sealed and quickly centrifuged, then analyzed by the LightCycler 480 Roche ${ }^{\circledR}$ (Rotkreuz, Switzerland) starting with one cycle at $95^{\circ} \mathrm{C}$ for $2 \mathrm{~min}$, then 30 amplification cycles at $95^{\circ} \mathrm{C}$ for $30 \mathrm{~s}$ and $60^{\circ} \mathrm{C}$ for $30 \mathrm{~s}$.

The amplification efficiency of qPCR primers was assessed by 10 -fold sample serial dilutions. Specificity was determined for each reaction from the dissociation curve of the qPCR products, obtained by following the SyberGreen fluorescent level during gradual heating from 60 to $95^{\circ} \mathrm{C}$. Based on these indicators, non-conforming data were not analyzed (ND in Table 2). Following the $2^{-\Delta \mathrm{Ct}}$ method described by Livak and Schmittgen (2001) [81], genes of interest were standardized by the average cycle thresholds $(\mathrm{Ct})$ from the reference genes $\beta$-actin and rpl7 [82]. Gills and visceral mass gene expression data are presented in Table 2.

\subsection{Statistical Analysis}

To satisfy the conditions for parametric analyses, raw data were transformed by commonly used functions (inverse square root or decimal logarithm). Normality was then confirmed using the Shapiro-Wilk test, and homoscedasticity was confirmed by the Student test $(\alpha=0.05)$. Transformed data were then compared between each treatment and concentration exposure using a two-way analysis of variance (ANOVA). The significant differences were identified by a post-hoc Tukey HSD test on Prism 8.0 for gene expression and the Bonferroni test on SigmaPlot 12.0 for arsenic dosage. 


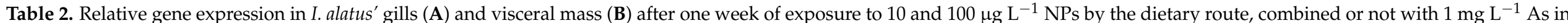

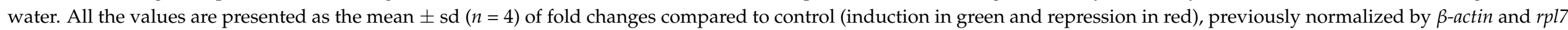

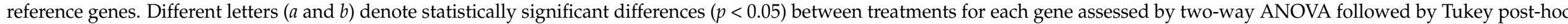
test. / indicates no statistically significant differences with the control.

\begin{tabular}{|c|c|c|c|c|c|c|c|c|c|c|c|c|c|c|}
\hline \multicolumn{15}{|c|}{ A-Gill. } \\
\hline Functions & Genes & $\begin{array}{c}N P G \\
10\end{array}$ & $\begin{array}{c}P S C \\
10\end{array}$ & $\begin{array}{c}P S L \\
10\end{array}$ & $\begin{array}{l}N P G \\
100\end{array}$ & $\begin{array}{c}P S C \\
100\end{array}$ & $\begin{array}{c}P S L \\
100\end{array}$ & As & $\begin{array}{c}A s+N P G \\
10\end{array}$ & $\begin{array}{c}A s+P S C \\
10\end{array}$ & $\begin{array}{c}A s+P S L \\
10\end{array}$ & $\begin{array}{c}A s+N P G \\
100\end{array}$ & $\begin{array}{c}A s+P S C \\
100\end{array}$ & $\begin{array}{c}A s+P S L \\
100\end{array}$ \\
\hline \multirow[t]{2}{*}{ Endocytosis } & $c a v$ & / & / & I & $\begin{array}{c}0.14 \pm \\
0.21 a\end{array}$ & $\begin{array}{l}2.78 \pm \\
1.10 b\end{array}$ & I & I & / & I & I & I & I & I \\
\hline & cltc & I & I & I & I & I & I & I & I & I & I & I & I & I \\
\hline \multirow{2}{*}{$\begin{array}{l}\text { Cell cycle } \\
\text { regulation }\end{array}$} & $b a x$ & I & ND & $\mathrm{ND}$ & / & ND & $\mathrm{ND}$ & $\begin{array}{c}0.03 \pm \\
0.01 a\end{array}$ & $\begin{array}{c}0.28 \pm \\
0.29 a\end{array}$ & ND & ND & / & ND & ND \\
\hline & gadd45 & l & $\begin{array}{c}0.20 \pm \\
0.06 a\end{array}$ & $\begin{array}{l}0.14 \pm \\
0.03 a b\end{array}$ & / & $\begin{array}{c}0.35 \pm \\
0.14 a\end{array}$ & $\begin{array}{l}0.29 \pm \\
0.11 a b\end{array}$ & / & / & $\begin{array}{c}0.11 \pm \\
0.01 b\end{array}$ & $\begin{array}{l}0.17 \pm \\
0.07 a b\end{array}$ & / & $\begin{array}{c}0.11 \pm \\
0.04 b\end{array}$ & $\begin{array}{c}0.11 \pm \\
0.01 b\end{array}$ \\
\hline \multirow{3}{*}{$\begin{array}{l}\text { Oxidative } \\
\text { stress }\end{array}$} & cat & / & I & $\begin{array}{c}0.08 \pm \\
0.02 a\end{array}$ & $\begin{array}{l}7.13 \pm \\
3.29 b\end{array}$ & $\mathrm{ND}$ & $\begin{array}{l}4.50 \pm \\
1.54 b\end{array}$ & / & / & ND & $\begin{array}{l}0.07 \pm \\
0.08 a c\end{array}$ & I & $\begin{array}{c}0.12 \pm \\
0.04 a\end{array}$ & $\begin{array}{c}0.01 \pm \\
0.00 c\end{array}$ \\
\hline & gapdh & / & I & I & / & ND & I & / & / & I & / & / & / & / \\
\hline & sod1 & I & $\begin{array}{c}0.33 \pm \\
0.05 a\end{array}$ & $\begin{array}{c}0.17 \pm \\
0.07 a\end{array}$ & I & $\mathrm{ND}$ & $\begin{array}{l}7.89 \pm \\
1.13 b\end{array}$ & $\begin{array}{c}2.86 \pm \\
0.68 b\end{array}$ & / & $\begin{array}{c}0.30 \pm \\
0.10 a\end{array}$ & / & / & I & / \\
\hline Detoxification & $m d r$ & I & I & I & T & ND & I & I & 1 & I & I & I & 1 & I \\
\hline \multirow{2}{*}{$\begin{array}{l}\text { Mitochondrial } \\
\text { metabolism }\end{array}$} & $12 S$ & / & I & / & / & $\begin{array}{c}0.43 \pm \\
0.11 a\end{array}$ & / & / & / & / & $\begin{array}{c}0.24 \pm \\
0.05 a\end{array}$ & ND & $\begin{array}{c}0.32 \pm \\
0.12 a\end{array}$ & $\begin{array}{c}0.30 \pm \\
0.11 a\end{array}$ \\
\hline & $\operatorname{cox} 1$ & / & / & / & / & / & / & $\begin{array}{c}7.33 \pm \\
3.81 a\end{array}$ & / & / & / & I & / & $\begin{array}{c}0.22 \pm \\
0.11 b\end{array}$ \\
\hline Functions & Genes & $\begin{array}{c}N P G \\
10\end{array}$ & $\begin{array}{c}P S C \\
10\end{array}$ & $\begin{array}{c}P S L \\
10\end{array}$ & $\begin{array}{c}N P G \\
100\end{array}$ & $\begin{array}{c}P S C \\
100\end{array}$ & $\begin{array}{c}P S L \\
100\end{array}$ & As & $\begin{array}{c}A s+N P G \\
10\end{array}$ & $\begin{array}{c}A s+P S C \\
10\end{array}$ & $\begin{array}{c}A s+P S L \\
10\end{array}$ & $\begin{array}{c}A s+N P G \\
100\end{array}$ & $\begin{array}{c}A s+P S C \\
100\end{array}$ & $\begin{array}{c}A s+P S L \\
100\end{array}$ \\
\hline \multirow[t]{2}{*}{ Endocytosis } & $c a v$ & / & / & / & l & ND & I & $\begin{array}{c}33.74 \pm \\
23.30 a\end{array}$ & $\begin{array}{c}0.13 \pm \\
0.05 b\end{array}$ & I & l & / & $\begin{array}{l}15.62 \pm \\
11.55 a\end{array}$ & / \\
\hline & cltc & I & I & I & / & / & $3.39 \pm 1.32$ & / & I & / & l & / & / & I \\
\hline \multirow{3}{*}{$\begin{array}{l}\text { Cell cycle } \\
\text { regulation }\end{array}$} & $b a x$ & I & I & $\begin{array}{c}0.18 \pm \\
0.04 a\end{array}$ & I & I & I & $\begin{array}{c}0.03 \pm \\
0.01 b\end{array}$ & $\begin{array}{l}0.07 \pm \\
0.06 a b\end{array}$ & $\begin{array}{c}0.18 \pm \\
0.03 a\end{array}$ & ND & $\begin{array}{c}0.14 \pm \\
0.03 a\end{array}$ & I & ND \\
\hline & gadd45 & / & $\begin{array}{c}0.21 \pm \\
0.10 a\end{array}$ & $\begin{array}{c}0.24 \pm \\
0.04 a\end{array}$ & / & $\begin{array}{c}0.18 \pm \\
0.13 a\end{array}$ & / & / & / & $\begin{array}{c}0.18 \pm \\
0.04 a\end{array}$ & $\begin{array}{c}0.18 \pm \\
0.04 a\end{array}$ & I & $\begin{array}{c}0.21 \pm \\
0.11 a\end{array}$ & $0.23 \pm 0.11 a$ \\
\hline & $p 53$ & / & I & / & I & I & I & I & I & / & I & I & / & I \\
\hline
\end{tabular}


Table 2. Cont

\begin{tabular}{|c|c|c|c|c|c|c|c|c|c|c|c|c|c|c|}
\hline \multicolumn{15}{|c|}{ B-Visceral mass. } \\
\hline Functions & Genes & $\begin{array}{c}N P G \\
10\end{array}$ & $\begin{array}{c}P S C \\
10\end{array}$ & $\begin{array}{c}P S L \\
10\end{array}$ & $\begin{array}{c}N P G \\
100\end{array}$ & $\begin{array}{c}P S C \\
100\end{array}$ & $\begin{array}{c}P S L \\
100\end{array}$ & As & $\begin{array}{c}A s+N P G \\
10\end{array}$ & $\begin{array}{c}A s+P S C \\
10\end{array}$ & $\begin{array}{c}A s+P S L \\
10\end{array}$ & $\begin{array}{c}A s+N P G \\
100\end{array}$ & $\begin{array}{c}A s+P S C \\
100\end{array}$ & $\begin{array}{c}A s+P S L \\
100\end{array}$ \\
\hline \multirow{3}{*}{$\begin{array}{c}\text { Oxidative } \\
\text { stress }\end{array}$} & cat & / & / & / & / & / & / & / & / & ND & ND & / & / & ND \\
\hline & gapdh & / & $\begin{array}{c}1.66 \pm \\
0.15 a\end{array}$ & $\begin{array}{c}1.35 \pm \\
0.08 a\end{array}$ & / & / & $\begin{array}{c}2.89 \pm \\
1.11 a\end{array}$ & / & $\begin{array}{c}0.30 \pm \\
0.20 b\end{array}$ & / & / & / & / & $\begin{array}{c}1.81 \pm \\
0.99 a\end{array}$ \\
\hline & $\operatorname{sod} 1$ & $\begin{array}{c}0.49 \pm \\
0.29 a \\
\end{array}$ & / & $\begin{array}{c}0.42 \pm \\
0.28 a \\
\end{array}$ & $\begin{array}{c}0.49 \pm \\
0.41 a \\
\end{array}$ & $\begin{array}{c}0.29 \pm \\
0.03 a \\
\end{array}$ & $\begin{array}{c}7.63 \pm \\
3.18 b \\
\end{array}$ & / & / & $\begin{array}{c}0.26 \pm \\
0.05 a \\
\end{array}$ & $\begin{array}{c}0.36 \pm \\
0.14 a \\
\end{array}$ & / & / & $\begin{array}{c}0.39 \pm \\
0.26 a \\
\end{array}$ \\
\hline Detoxificatio & $m d r$ & / & / & / & / & / & $\begin{array}{c}2.73 \pm \\
0.59 a\end{array}$ & / & $\begin{array}{c}0.47 \pm \\
0.36 b\end{array}$ & / & / & $\begin{array}{c}0.26 \pm \\
0.10 b\end{array}$ & / & / \\
\hline Mitochondrial & $12 S$ & / & / & / & / & / & / & / & / & / & / & / & / & / \\
\hline metabolism & $\operatorname{cox} 1$ & / & / & / & / & / & I & I & I & / & / & / & / & / \\
\hline
\end{tabular}




\section{Results}

\subsection{Oysters Biometric Parameters and Arsenic Bioaccumulation}

Mortality during the exposure was negligible $(<4 \%)$. No significant differences were observed for the total fresh tissue weights and the CI among treatments (data shown in Supplementary Materials Figure S3). Field-collected control animals had an average concentration of $75 \mu \mathrm{g} \mathrm{g}^{-1}$ As in gills and $133 \mu \mathrm{g} \mathrm{g}^{-1}$ As in visceral mass (Figure 3). Asexposed oysters yielded approximately 1.5 times greater As concentrations than the control oysters in both tissues (Figure 3). However, there were no statistical differences in As concentrations between the As and the NPG+As exposed oysters, nor between the two levels of NP exposure.

\subsection{Relative Genes Expression in Gills and Visceral Mass}

The expression of a suite of genes involved in five main biological functions, endocytosis (cav and cltc), cell cycle regulation ( $p 53$, gadd45, and bax), oxidative stress (sod1, cat, and gapdh), mitochondrial metabolism (cox1 and 12S), and detoxification ( $m d r)$ were assessed in gills and visceral mass (Table 2).

\subsubsection{Single Nanoplastic Treatments}

In gills, the low exposure level of $10 \mu \mathrm{g} \mathrm{L}^{-1}$ to NPs revealed few genes with modulated expression, except repression of gadd45 and sod1 for PSC and PSL, as well as cat for PSL (Table 2). In contrast, for NP treatments at $100 \mu \mathrm{g} \mathrm{L}{ }^{-1}$, NPG induced the expression of cat and PSL the expression of sod1, two genes implied in the response to oxidative stress. Additionally, PSC induced endocytosis by caveolin upregulation, while both PSC and PSL repressed gadd 45 expression, as observed for the lower concentration.

In visceral mass, the expression pattern of gadd 45 revealed a significant downregulation for both PSC and PSL at $10 \mu \mathrm{g} \mathrm{L}^{-1}$, but only for PSC at $100 \mu \mathrm{g} \mathrm{L}^{-1}$ (Table 2). At $10 \mu \mathrm{g} \mathrm{L}^{-1}$, PSC and PSL treatments revealed the induction of gapdh, which is implied in oxidative stress and further increased for PSL at $100 \mu \mathrm{g} \mathrm{L}^{-1}$. Moreover, the mRNA level of sod1 was significantly upregulated for PSL at $100 \mu \mathrm{g} \mathrm{L}{ }^{-1}$, in contrast to most of the other NP treatments for which sod1 was repressed. The highest modulations of gene expression were observed for PSL at $100 \mu \mathrm{g} \mathrm{L}^{-1}$ by oxidative stress gene responses in addition to induction of cltc implied in endocytosis and $m d r$ for detoxification mechanisms.

\subsubsection{Single Arsenic Treatment}

In gills, As significantly induced the expression of cox1, revealing the mitochondrial metabolism impairment, and of sod1, revealing the oxidative stress burden. In parallel, bax was repressed.

In the visceral mass, interestingly, the expression of cav was significantly upregulated by the As treatment. In contrast, bax was significantly repressed. No statistical transcriptional changes were seen for $p 53$ expression between treatments; however, the ANOVA was significant for the test $(p=0.0009)$, which supports $p 53$ inhibition for As treatment.

\subsubsection{Nanoplastic Arsenic Treatments}

In gills, the presence of NPs totally inhibited the induction of sod1 and cox1 previously observed with As alone, whatever the level of exposure or the type of NPs. The presence of As also canceled the induction of cat observed with NPG at $100 \mu \mathrm{g} \mathrm{L}^{-1}$ (return to the basal level of control) or even repressed its expression with PSL at $100 \mu \mathrm{g} \mathrm{L}^{-1}$ (reduction of $2222 \%$ compared to control).

In the visceral mass, the presence of NPs canceled the induction of cav observed with As alone, except for PSC+As at $100 \mu \mathrm{g} \mathrm{L}^{-1}$. In the same way, the induction of cltc observed for PSL at $100 \mu \mathrm{g} \mathrm{L}^{-1}$ was canceled in the presence of As. The expression of bax showed a significant downregulation for NPG+As at both 10 and $100 \mu \mathrm{g} \mathrm{L}^{-1}$, and only at $10 \mu \mathrm{g} \mathrm{L}^{-1}$ for PSC+As. Since PSL+As could not be detected, it is worth noting bax downregulation for PSL also at $10 \mu \mathrm{g} \mathrm{L}{ }^{-1}$. The same downregulation pattern was 
shared in gadd45 for PSC+As and PSL+As treatments at both concentrations. For gapdh expression, there was a significant downregulation for NPG+As at $10 \mu \mathrm{g} \mathrm{L}^{-1}$. The $\operatorname{sod} 1$ expression response for PSL+As at $100 \mu \mathrm{g} \mathrm{L}^{-1}$ was significantly inhibited compared to the PSL treatment, and interestingly, aljso significantly lower than for the arsenic treatment. Expression of $m d r$ was not modulated except for the NPG+As treatment, significantly inhibited at 10 and $100 \mu \mathrm{g} \mathrm{L}^{-1}$.

\section{Discussion}

\subsection{Arsenic Uptake and Bioaccumulation in Oysters}

The statistical analyses conducted on biometric parameters do not show any significant differences for the measured shell length and fresh tissue mass, nor for the calculated CI (Figure 3). Potential variations in As bioaccumulation in tissues can thus not be attributable to differences in biometric parameters.

The total As tissue bioaccumulation measured in controls demonstrated the biogeochemical background of Guadeloupean mangroves. These levels provide us with the environmental As baseline of I. alatus in their native habitat. Despite these rather high As values, they are comparable with a reviewed range of bioaccumulated As occurring naturally in bivalves $[60,83]$. For each treatment, total As bioaccumulation in gills is around half the As bioaccumulation in visceral mass. These results confirm the organ's function towards chronic metal exposure with higher As levels in the visceral mass (storage organ; [84,85]) compared to the gills (transfer organ; [54,86]). This present study used $1 \mathrm{mg} \mathrm{L}^{-1}$ As, which allowed an increase in As bioaccumulation for both tissues after a short-term exposure (one week). No speciation analysis has been conducted, as we did not aim to address the As behavior in this study. Given chemical reactions in seawater, the initial As form (arsenate) underwent speciation changes [87-89]. Thus, it has to be kept in mind that total As results cannot be interpreted as the equivalent of the initial As form. Therefore, As treatment and total As results should be seen as a positive control. Seawater analysis from the oysters' reference site was also conducted. For all sampling stations, total As concentrations measured were below the limit of detection. The chronic exposure of $I$. alatus is most likely responsible for the tissue bioaccumulation found in controls. Under environmental conditions, oyster exposure to As most likely came from sediment through the waterborne route $[63,64,83]$ and phytoplankton through the dietary route, since microalgae bioaccumulate inorganic As forms [60,89,90]. Concentration has been only measured in NPG+As treatments, as NPG were the only nanoparticles carrying an initial As burden. Thus, NPG were the most indicated NPs to increase the As bioaccumulation in I. alatus tissues. Yet, there were no statistical differences in As bioaccumulation between the As and the NPG+As treatments, at 10 and $100 \mu \mathrm{g} \mathrm{L}^{-1} \mathrm{NPG}$ concentrations for both tissues. Similarly, Freitas et al. (2018) did not observe an increased As bioaccumulation in clams in the presence of As $\left(0.1 \mathrm{mg} \mathrm{L}^{-1}\right)$ combined with multi-walled carbon nanotubes $\left(0.1 \mathrm{mg} \mathrm{L}^{-1}\right)$ [65]. Our results underlined that As bioaccumulation in both tissues was only driven by As treatment. Ultimately, the presence of NPs at these low concentrations did not affect the As total uptake of I. alatus.

\subsection{Microalgae Growth under Nanoplastic Exposure}

Phytoplankton organisms like microalgae are primary producers. They are therefore a keystone in aquatic food webs. Yet, NPs are known to interact with micrometric compounds such as microalgae due to their colloidal behavior in water [12,91,92]. To anticipate NP effects on T. lutea growth, a $96 \mathrm{~h}$ exposure was conducted with NPG, PSC, and PSL solutions at 10 and $100 \mu \mathrm{g} \mathrm{L}^{-1}$ (Figure 1).

No significant changes were observed under any NP treatments. Noteworthily, higher optical density dispersions happened at $72 \mathrm{~h}$ for both NP concentrations. Thus, we decided to expose T. lutea for $48 \mathrm{~h}$ to NP solutions prior to feeding oysters. NPs' availability in our trophic experiment is believed to be mainly driven by their filtration rate [39,93]. Therefore, special attention was given to feed oysters with consistent microalgae concentrations 
among treatments. NPs were expected to be adsorbed or internalized after $48 \mathrm{~h}$ exposure, and to potentially trigger physiological changes on the microalgae membrane. To assess the fate of NPG, PSC, and PSL at 10 and $100 \mu \mathrm{g} \mathrm{L}^{-1}$, optical microscopic observations were conducted on NP-T. lutea. We did not observe significant effects for any treatments. Yet, in a similar experiment (Lebordais et al., 2021) [94], we attested PSL adsorption on T. lutea surface for a concentration grade including 10 and $100 \mu \mathrm{g} \mathrm{L}^{-1}$ by scanning electron microscopy (SEM).

\subsection{Effects of Nanoplastics and Arsenic on Genes Expression in Oysters \\ 4.3.1. Single Nanoplastic Treatments}

Our results showed significant downregulation of the gadd45 mRNA level for PSC and PSL treatments at both concentrations, except for PSL $100 \mu \mathrm{g} \mathrm{L}^{-1}$ in visceral mass (Table 2). Given that the main role of gadd45 is to maintain genomic stability, this gene is strongly regulated by DNA damaging agents like metals, but also growth-arresting signals [74]. Oxidative stress has also been established by in vitro and in vivo studies as an early indicator of NP toxicity in freshwater bivalves $[39,95]$. Thus, NP toxicity is mainly exerted through two pathways: either directly by interacting with the cellular contents including DNA, or indirectly by ROS release, known for causing nucleotide adducts [96,97]. Significant upregulation for PSL treatment at $100 \mu \mathrm{g} \mathrm{L}{ }^{-1}$ of sod1 and cat in gills, as well as sod1 and gapdh in visceral mass, might imply higher ROS production. The same scenario appears in gills for NPG treatment at $100 \mu \mathrm{g} \mathrm{L}^{-1}$ with the induction of cat, suggesting oxidative stress especially for NPG and PSL exposure conditions. Also for PSL at $100 \mu \mathrm{g} \mathrm{L}^{-1}$, the induction of cltc suggests a facilitated uptake of this kind of NPs in the cells. Yet, the detoxification process of $m d r$ is also overexpressed and thus reveals the potential ability of cells to expulse these NPs. Our overall results thus showed different patterns of effects among NPs, thus shedding light on the necessity to use several NPs for ecotoxicological studies. Unlike conventional commercial nanoparticles [20,98,99], here we used functionalized PSL nanoparticles with no additives to avoid additional toxicity [48]. Indeed, most commonly used additives like sodium dodecyl sulfate, Tween ${ }^{\circledR}$, and Triton- $X{ }^{\circledR}$ can induce toxic effects on aquatic organisms [100-102]. Recently, it has been demonstrated by Pikuda et al., (2019) that the toxicity of commercial PSL-COOH on daphnia was coming from its bactericide additive (sodium azide) [103]. Additionally, since carboxylated functions ensured PSL stability, we propose its higher availability by endocytosis. It can be hypothesized that PSL was either more absorbed or adsorbed by microalgae before being ingested by oysters. Nanoparticles' instability has indeed been acknowledged for turning aggregates into bigger particles (e.g., MPs), particularly in seawater solutions [10,29,31]. Natural Organic Matter has also been addressed to affect PS NPs aggregation, depending on the water chemistry and its ions valence [104]. Moreover, Mao et al. (2020) observed less aggregation from PS NPs in the presence of algal extracellular polymeric substances [31]. Interestingly, they also observed less aggregation from artificially UV-aged PS NPs, since the formation of carbonyl groups enabled their stabilization. In our experiment, lower stability has been particularly observed for NPG compared to the other NPs. Therefore, the aggregation of NPG may have led to less interaction with microalgae during the exposure. This could explain its fewer toxicity effects compared to PSC and PSL in visceral mass. As such, our results underlined the value to assess NPs' stability in the exposure media [26,51] and to further study comparative NP effects. This is also supported by Baudrimont et al.'s (2020) study [6], which revealed a significantly higher production of pseudofeces by Corbicula fluminea after $36 \mathrm{~h}$ of exposure to $1000 \mu \mathrm{g} \mathrm{L}^{-1}$ environmental NPs, which was not observed under conventional commercial polyethylene NP exposure. These comparative NP exposures, along with our current results, suggest different hazardous effects between environmental and conventional plastic nanoparticles. Thereby, we would like to raise awareness of the underestimation of NP ecotoxicity in the literature, as most conventional commercial polystyrene nanoplastics are being used. 


\subsubsection{Single Arsenic Treatment}

Data showed bax to be downregulated following As treatments in both tissues. It has already been described in humans that As is able to inhibit the repair of DNA damages, leading to carcinogenic effects [105]. In gills, the significant overexpression of sod1 and the upregulation of cox 1 should indicate in this tissue generation of oxidative stress and mitochondrial metabolism disruption, respectively. Our results indeed revealed a metal effect similar to that observed by cox 1 upregulation in C. fluminea hemocytes exposed to ionic $\mathrm{Au}$ for 28 days [39].

\subsubsection{NPs+As Treatments}

Expression of $m d r$ revealed opposite responses at $100 \mu \mathrm{g} \mathrm{L}{ }^{-1}$ between PSL treatment's upregulation and NPG+As treatment's downregulation in visceral mass. MXR pumps work as a cytoprotective system by excreting exogenous compounds. Nonetheless, it is sensitive to both physical and chemical stressors [106]. NP toxicity might be increased by As interaction with NPG, since the detoxification process can be inhibited in the presence of metals [107]. Similar results were found for encoded MXR-related proteins in Mytilus galloprovincilalis digestive glands exposed to $0.75 \mu \mathrm{M} \mathrm{Hg}^{2+}$ for six days [80]. Due to physical and chemical fragmentation factors [11,108,109], NPG surfaces are heterogeneously degraded and expected to be the most environmentally representative NPs in aquatic ecosystems. As proposed by Lambert and Wagner (2016), Ter Halle et al. (2017), and Baudrimont et al. (2020) higher reactivity of secondary plastic surfaces enables increased availability for contaminants to be adsorbed onto them $[6,9,28]$. This experiment evaluated NP affinities towards As, showing more interaction for NPG and PSL (as expected from NPG degraded surfaces and PSL carboxylated surface groups). Previous studies recorded changes in bivalve closure rhythm under metal exposure, ultimately affecting their filtration $[110,111]$. This stress is most likely to be seen in the transcriptional response of gills, but also in visceral mass tissues. Similar bioavailability of As for I. latus most likely explains the converging responses between NPs+As treatments and single As treatment for cell cycle regulation (bax). Yet, we observed lower toxicity in NPs+As treatments compared to single As treatments for endocytosis (cav), oxidative stress (sod1), and mitochondrial metabolism (cox1). Antagonist effects have been recently documented for MP-NP exposures combined with metals [112,113] including As [66]. Antagonist effects refer to significantly lower responses in combined contaminant treatments (NPs+As) compared to the control and both individual contaminants [114]. However, we underline here basal mRNA levels for combined NPs+As treatments. We are not aware of any earlier studies showing a decrease of NPs' gene expression effects when in the presence of any metal exposure. Therefore, we aim to repeat this experiment with another oyster species to confirm this novel finding.

\subsection{Models of Trophic Exposure Effects on the Studied Gene Functions}

Based on the genes mRNA levels, Figure 4 sheds light on the main findings of this present study. Induction arrows show the presence of a biological effect for a given treatment, regardless of genes' up- or downregulation. Prevention arrows represent the absence of a biological effect for NPs+As treatment. Therefore, the gene response is equivalent to the control treatment. An antagonist arrow shows the presence of a biological effect for NPs+As treatment. Therefore, the gene response is significantly lower than the control and absent in NP treatments.

In gills (Figure 4A), PSC internalization can be hypothesized at $100 \mu \mathrm{g} \mathrm{L}^{-1}$ by cav induction. Since a fraction of PSC might be aggregated, resulting in bigger particles similar to MPs, a higher PSC concentration might be required to witness their internalization. Polystyrene nanoplastics (PS NPs) were consistent in DNA damage, showing no change of toxicity for PSC+As and PSL+As treatments on gadd 45 repression. Additionally, the change of bax expression for NPG+As treatment at $10 \mu \mathrm{g} \mathrm{L}^{-1}$ was most likely caused by As. Contrary to what was expected, no synergetic effects were observed between As and NPs in combined treatments. At a subcellular level, the As treatment alone affected mitochondria 
homeostasis by cox 1 upregulation, but once in presence of any NPs, cox1 upregulation was canceled. Thus, we hypothesize that NPs' presence could decrease the As availability, most likely through As adsorption on NPs, but no affirmation can be done, as there were no significant differences. In the presence of As, there was an inhibition of cat expression for PSL +As treatments at 10 and $100 \mu \mathrm{g} \mathrm{L}^{-1}$, contrary to NP single treatments. Moreover, As alone induced oxidative stress revealed by sod1 expression and so did the PSL treatment at $100 \mu \mathrm{g} \mathrm{L}^{-1}$, but once As was in presence of PSL (PSL+As treatment), a putative decrease of oxidative stress was observed. Therefore, data highlight a potential protective role of PSL against the oxidative stress caused by As, but also a protective role of As toward the oxidative stress generated by NPG and PSL at $100 \mu \mathrm{g} \mathrm{L}^{-1}$ revealed by the cat upregulation.
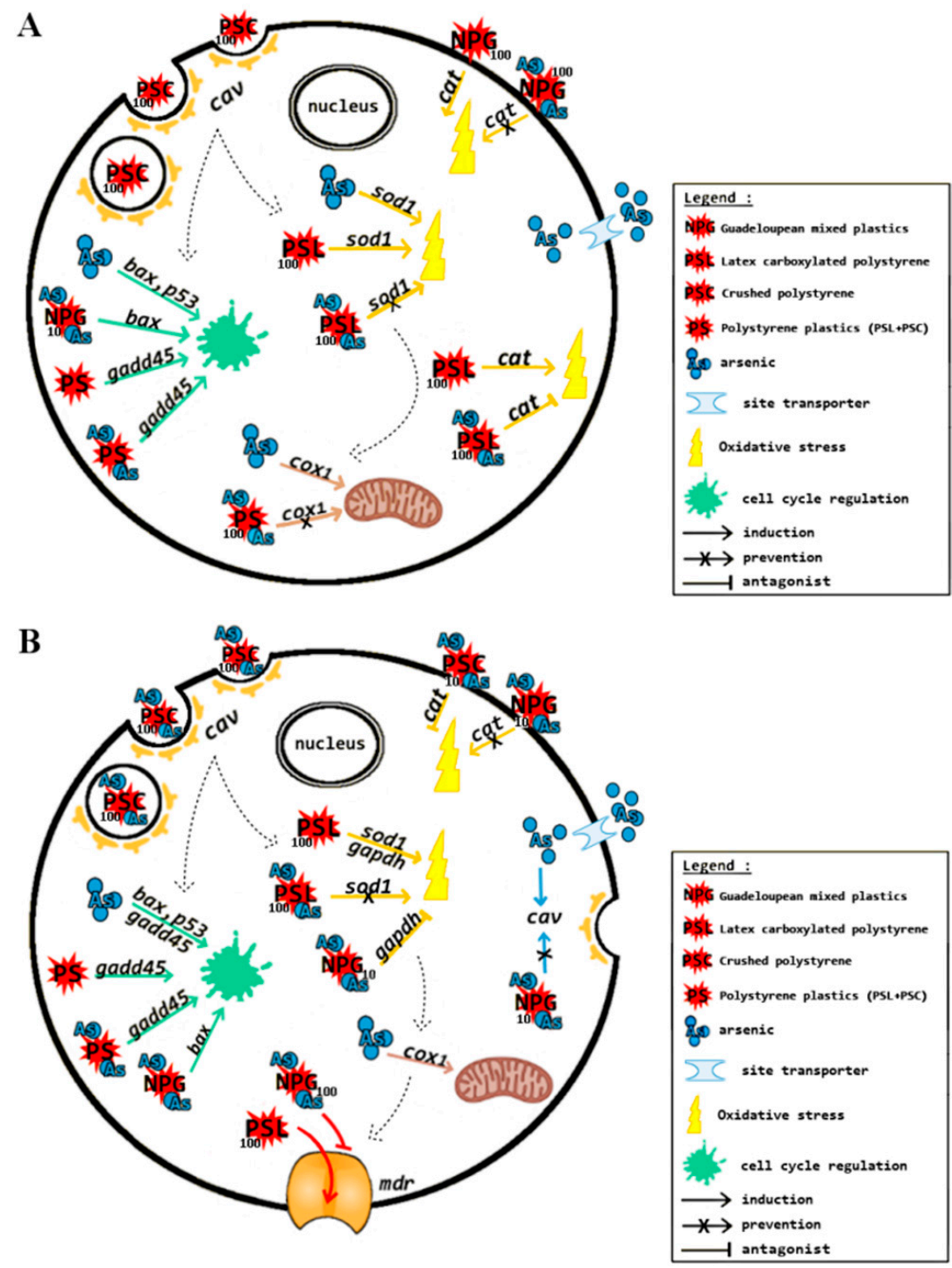

Figure 4. Schematics of suggested cellular effects of NPs and As in I. alatus' gills (A) and visceral mass (B) tissues.

In visceral mass (Figure 4B), data suggest PSC internalization in the presence of As at $100 \mu \mathrm{g} \mathrm{L}^{-1}$ by cav induction, leading to membrane invagination. PS NPs triggered DNA damage given the gadd 45 repression. Based on their physico-chemical characteristics, PSC and PSL yielded a low and very low endogenous ROS burden, respectively. Thus, DNA damage most likely came from the physical nanoparticle toxicity, excluding additional toxicity from As in PSC+As and PSL+As treatments. However, an opposite pattern was observed for NPG+As, where the bax mRNA level decreased once NPG were in presence 
of As. Therefore, As interaction showed different effects among NPs toward cell cycle regulation and apoptosis. Moreover, PSL and NPG expressed an opposite $m d r$ response at $100 \mu \mathrm{g} \mathrm{L}^{-1}$. Indeed, as PSL were very stable, an increased exposure seemed to lead to a greater induction response from the cell to expel them. Oxidative stress was triggered by PSL at $100 \mu \mathrm{g} \mathrm{L}^{-1}$ inducing sod1 regulation, but was canceled in presence of As (PSL+As treatment), while gapdh expression was inhibited by NPG+As treatment at $10 \mu \mathrm{g} \mathrm{L}^{-1}$. Thus, As presence seemed to cancel the oxidative stress production seen for NP single treatments. It has to be kept in mind that NPG were the most weathered NPs, with high porosity and high surface oxidative degree that potentially increased its interaction with As. The same logic applies for PSL by As adsorption on its carboxylated functions. Noteworthily, As treatment induced endocytosis activation by cav expression. Again, we may have observed As interaction with NPs through adsorption that led to canceling cav induction inNPG+As treatment at $10 \mu \mathrm{g} \mathrm{L}^{-1}$.

\section{Conclusions}

We demonstrated that sublethal exposures of NPs impaired cellular functions at the molecular level on native Guadeloupean oysters. Among our three NP solutions, PSL treatments showed the most consistent toxic effects by triggering oxidative stress and cell cycle regulation in gills and visceral mass tissues. These results shed light on the interest to use PSL additives-free nanoparticles with surface functionalized groups (e.g., carboxyl group) rather than conventional commercial PSL. Similarly, but with fewer effects observed, PSC toxicity came most likely from their irregular surface, with a highly specific surface that potentially enabled more adsorption on the microalgae surface. Interestingly, NPG treatments also showed toxic effects, but fewer than PSL by only triggering oxidative stress in gills. In light of these results, we suggest that studies might include more complex environmental NPs in their study design. Moreover, to our knowledge, we present the first results showing a specific response of NPs+As exposure with a protective effect on oxidative stress and on endocytosis. All these results underline the threat of plastics for marine wildlife and the need to study crossed effects between NPs and other contaminants.

Supplementary Materials: The following are available online at https:/ / www.mdpi.com/article/10 .3390/nano11051151/s1: Figure S1: DLS measures of NPG nanoparticles, Figure S2: DLS measures of PSC nanoparticles, Figure S3: Isognomon alatus biometric parameters, Table S1: Isognomon alatus targeted genes for qPCR.

Author Contributions: Conceptualization: V.S.L. and M.B.; methodology: M.L. and Z.V.; formal analysis: M.L.; investigation: M.L. and Z.V.; resources: J.G., V.S.L., and M.B.; writing—original draft preparation: M.L.; writing—review and editing: Z.V., J.G., V.S.L., and M.B.; supervision: V.S.L. and M.B.; project administration: M.B.; funding acquisition: J.G., V.S.L., and M.B. All authors have read and agreed to the published version of the manuscript.

Funding: This research was funded by the French National Agency of Research (ANR-1-17-CE340008: PEPSEA to MB), the Investments for the Future Program, within the Cluster of Excellence COTE (ANR-1-10-LABX-45 to MB), the Interaction Nickel-Nanoplastics in Mangroves Of New-Caledonia (project EC2CO), the E2S-Pau, the Nouvelle-Aquitaine Region (EN-Pi project), and by the Canada Research Chair program (950-232235 to VSL).

Institutional Review Board Statement: "Not applicable" for studies not involving humans or vertebrates.

Informed Consent Statement: Not applicable.

Data Availability Statement: Data available on request. The data presented in this study are available on request from the corresponding author. 
Acknowledgments: The authors would like to thank Adeline Arini for her valuable help to design the experimental protocol and conduct molecular biology investigations, Anthony Bertucci for his help to design gene primers on oysters, Patrice Gonzalez and Cerise Daffe for their formation in molecular biology, and Pierre-Yves Gourves for sample mineralization and arsenic analyses. We acknowledge Bruno Grassl, Hind El Hadri, and Stephanie Reynaud for providing the free-soap carboxylated polystyrene nanoparticles of latex. The authors also appreciated the unknown referee's helpful comments.

Conflicts of Interest: The authors declare that the research was conducted in the absence of any financial or ownership conflict that could present competing interests.

\section{References}

1. UNEP. Marine Litter - Trash that Kills; United Nations Environment Programme; Swedish Environmental Protection Agency: Stockholm, Sweden, 2001.

2. Barnes, D.K.A.; Galgani, F.; Thompson, R.C.; Barlaz, M. Accumulation and fragmentation of plastic debris in global environments. Philos. Trans. R. Soc. B Biol. Sci. 2009, 364, 1985-1998. [CrossRef]

3. Briand, N. Familles de plastiques et leurs usages. Septième continent. MobiSci. Briand 2014.

4. Wright, S.L.; Kelly, F.J. Plastic and Human Health: A Micro Issue? Environ. Sci. Technol. 2017, 51, 6634-6647. [CrossRef]

5. Law, K.L.; Moret-Ferguson, S.; Maximenko, N.A.; Proskurowski, G.; Peacock, E.E.; Hafner, J.; Reddy, C.M. Plastic Accumulation in the North Atlantic Subtropical Gyre. Science 2010, 329, 1185-1188. [CrossRef]

6. Baudrimont, M.; Arini, A.; Guégan, C.; Venel, Z.; Gigault, J.; Pedrono, B.; Prunier, J.; Maurice, L.; Ter Halle, A.; Feurtet-Mazel, A. Ecotoxicity of polyethylene nanoplastics from the North Atlantic oceanic gyre on freshwater and marine organisms (microalgae and filter-feeding bivalves). Environ. Sci. Pollut. Res. 2020, 27, 3746-3755. [CrossRef]

7. Arthur, C.; Baker, J.; Bamford, H. Proceedings of the International Research Workshop on the Occurrence, Effects, and Fate of Microplastic Marine Debris, Tacoma, WA, USA, 9-11 September 2008; Technical Memorandum NOS-OR\&R-30; National Oceanic and Atmospheric Administration: Silver Spring, MD, USA, 2009.

8. Cai, M.; He, H.; Liu, M.; Li, S.; Tang, G.; Wang, W.; Huang, P.; Wei, G.; Lin, Y.; Chen, B.; et al. Lost but can't be neglected: Huge quantities of small microplastics hide in the South China Sea. Sci. Total Environ. 2018, 633, 1206-1216. [CrossRef]

9. Lambert, S.; Wagner, M. Characterisation of nanoplastics during the degradation of polystyrene. Chemosphere 2016, 145, 265-268. [CrossRef]

10. Gigault, J.; Balaresque, M.; Tabuteau, H. Estuary-on-a-chip: Unexpected results for nanoparticles fate and transport. Environ. Sci. Nano 2018, 5, 1231-1236. [CrossRef]

11. Koelmans, A.A.; Besseling, E.; Shim, W.J. Nanoplastics in the Aquatic Environment. Critical Review. Mar. Anthropog. Litter 2015, 325-340.

12. Gigault, J.; Ter Halle, A.; Baudrimont, M.; Pascal, P.-Y.; Gauffre, F.; Phi, T.-L.; El Hadri, H.; Grassl, B.; Reynaud, S. Current opinion: What is a nanoplastic? Environ. Pollut. 2018, 235, 1030-1034. [CrossRef] [PubMed]

13. Magrí, D.; Sánchez-Moreno, P.; Caputo, G.; Gatto, F.; Veronesi, M.; Bardi, G.; Catelani, T.; Guarnieri, D.; Athanassiou, A.; Pompa P.P.; et al. Laser Ablation as a Versatile Tool To Mimic Polyethylene Terephthalate Nanoplastic Pollutants: Characterization and Toxicology Assessment. ACS Nano 2018, 12, 7690-7700. [CrossRef]

14. Tien, C.; Chen, C.S. Patterns of metal accumulation by natural river biofilms during their growth and seasonal succession. Arch Environ. Contam. Toxicol. 2013, 64, 605-616. [CrossRef]

15. Suhrhoff, T.J.; Scholz-Bottcher, B.M. Qualitative impact of salinity, UV radiation and turbulence on leaching of organic plastic additives from four common plastics-A lab experiment. Mar. Pollut. Bull. 2016, 102, 84-94. [CrossRef] [PubMed]

16. Davranche, M.; Veclin, C.; Pierson-Wickmann, A.-C.; El Hadri, H.; Grassl, B.; Rowenczyk, L.; Dia, A.; Ter Halle, A.; Blancho, F.; Reynaud, S.; et al. Are nanoplastics able to bind significant amount of metals? The lead example. Environ. Pollut. 2019, 249, 940-948. [CrossRef] [PubMed]

17. El Hadri, H.; Gigault, J.; Mounicou, S.; Grassl, B.; Reynaud, S. Trace Element Distribution in Marine Microplastics Using Laser Ablation-ICP-MS. Mar. Pollut. Bull. 2020, 160, 111716. [CrossRef] [PubMed]

18. Gall, S.C.; Thompson, R.C. The impact of debris on marine life. Mar. Pollut. Bull. 2015, 92, 170-179. [CrossRef]

19. Lusher, A.L.; Welden, N.A.; Sobral, P.; Cole, M. Sampling, isolating and identifying microplastics ingested by fish and invertebrates. Anal. Methods 2017, 9, 1346-1360. [CrossRef]

20. Rossi, G.; Barnoud, J.; Monticelli, L. Polystyrene Nanoparticles Perturb Lipid Membranes. Phys. Chem. Lett. 2013, 5, 241-246. [CrossRef]

21. Manfra, L.; Rotini, A.; Bergami, E.; Grassi, G.; Faleri, C.; Corsi, I. Comparative ecotoxicity of polystyrene nanoparticles in natural seawater and reconstituted seawater using the rotifer Brachionus plicatilis. Ecotoxicol. Environ. Saf. 2017, 145, 557-563. [CrossRef]

22. Nel, A.; Xia, T.; Madler, L.; Li, N. Toxic Potential of Materials at the Nanolevel. Science 2006, 311, 622-627. [CrossRef]

23. Mattsson, K.; Hansson, L.A.; Cedervall, T. Nano-Plastics in the Aquatic Environment. Environ. Sci. Process. Impacts 2015, 17, 1712-1721. [CrossRef] 
24. Chae, Y.; An, Y.-J. Effects of Micro- and Nanoplastics on Aquatic Ecosystems: Current Research Trends and Perspectives. Mar. Pollut. Bull. 2017, 124, 624-632. [CrossRef]

25. Richardson, S.D.; Kimura, S.Y. Water Analysis: Emerging Contaminants and Current Issues. Anal. Chem. 2020, 92, 473-505. [CrossRef]

26. Quik, J.T.K.; Vonk, J.A.; Hansen, S.F.; Baun, A.; Van De Meent, D. How to assess exposure of aquatic organisms to manufactured nanoparticles? Environ. Int. 2011, 37, 1068-1077. [CrossRef]

27. Bergmann, M.; Gutow, L.; Klages, M. Nanoplastics in the Aquatic Environment. Critical Review. In Marine Anthropogenic Litter; Springer: Cham, Germany, 2015; pp. 325-340.

28. Ter Halle, A.; Jeanneau, L.; Martignac, M.; Jardé, E.; Pedrono, B.; Brach, L.; Gigault, J. Nanoplastics in the North Atlantic Subtropical Gyre. Environ. Sci. Technol. 2017, 51, 13689-13697. [CrossRef] [PubMed]

29. Hotze, E.M.; Phenrat, T.; Lowry, G.V. Nanoparticle Aggregation: Challenges to Understanding Transport and Reactivity in the Environment. J. Environ. Qual. 2010, 39, 1909. [CrossRef] [PubMed]

30. Corsi, I.; Cherr, G.N.; Lenihan, H.S.; Labille, J.; Hassellov, M.; Canesi, L.; Dondero, F.; Frenzilli, G.; Hristozov, D.; Puntes, V.; et al. Common Strategies and Technologies for the Ecosafety Assessment and Design of Nanomaterials Entering the Marine Environment. ACS Nano 2014, 8, 9694-9709. [CrossRef] [PubMed]

31. Mao, Y.; Li, H.; Huangfu, X.; Liu, Y.; He, Q. Nanoplastics display strong stability in aqueous environments: Insights from aggregation behaviour and theoretical calculations. Environ. Pollut. 2020, 258, 113760.

32. Kulkarni, R.; Deobagkar, D.; Zinjarde, S. Metals in mangrove ecosystems and associated biota: A global perspective. Ecotoxicol. Environ. Saf. 2018, 153, 215-228. [CrossRef] [PubMed]

33. Mitra, A. Sensitivity of Mangrove Ecosystem to Changing Climate; Springer: New Delhi, India, 2013; pp. $43-157$.

34. Carugati, L.; Gatto, B.; Rastelli, E.; Lo Martire, M.; Coral, C.; Greco, S.; Danovaro, R. Impact of mangrove forests degradation on biodiversity and ecosystem functioning. Sci. Rep. 2018, 8, 1-11. [CrossRef]

35. Cajaraville, M.P.; Bebianno, M.J.; Blasco, J.; Porte, C.; Sarasquete, C.; Viarengo, A. The use of biomarkers to asses the impact of pollution in coastal environment of the Iberian Peninsula: A practical approach. Sci. Total Environ. 2000, 247, 295-311. [CrossRef]

36. Baudrimont, M.; Schäfer, J.; Marie, V.; Maury-Brachet, R.; Bossy, C.; Boudou, A.; Blanc, G. Geochemical survey and metal bioaccumulation of three bivalve species (Crassostrea gigas, Cerastoderma edule and Ruditapes philipinarum) in the Nord Médoc salt marshes (Gironde estuary, France). Sci. Total Environ. 2005, 337, 265-280. [CrossRef] [PubMed]

37. Arini, A.; Baudrimont, M.; Feurtet-Mazel, A.; Coynel, A.; Blanc, G.; Coste, M.; Delmas, F. Comparison of periphytic biofilm and filtering bivalves metal bioaccumulation ( $\mathrm{Cd}$ and $\mathrm{Zn}$ ) to monitor hydrosystem restoration after industrial remediation: A year of biomonitoring. Environ. Monit. 2011, 13, 3386-3398. [CrossRef] [PubMed]

38. Aguirre-Rubí, J.R.; Luna-Acosta, A.; Etxebarría, N.; Soto, M.; Espinoza, F.; Ahrens, M.J.; Marigómez, I. Chemical contamination assessment in mangrove-lined Caribbean coastal systems using the oyster Crassostrea rhizophorae as biomonitor species. Environ. Sci. Pollut. Res. 2017, 25, 13396-13415. [CrossRef]

39. Arini, A.; Pierron, F.; Mornet, S.; Baudrimont, M. Bioaccumulation dynamics and gene regulation in a freshwater bivalve after aqueous and dietary exposures to gold nanoparticles and ionic gold. Environ. Sci. Pollut. Res. 2020, 27, 3637-3650. [CrossRef]

40. Baun, A.; Hartmann, N.B.; Grieger, K.; Kusk, K.O. Ecotoxicity of engineered nanoparticles to aquatic invertebrates: A brief review and recommendations for future toxicity testing. Ecotoxicology 2008, 17, 387-395. [CrossRef]

41. Tallec, K.; Paul-Pont, I.; Boulais, M.; Le Goïc, N.; González-Fernández, C.; Le Grand, F.; Bideau, A.; Quéré, C.; Cassone, A.L.; Lambert, C.; et al. Nanopolystyrene beads affect motility and reproductive success of oyster spermatozoa (Crassostrea Gigas). Nanotoxicology 2020, 14, 1039-1057. [CrossRef]

42. Cedervall, T.; Hansson, L.A.; Lard, M.; Frohm, B.; Linse, S. Food chain transport of nanoparticles affects behaviour and fat metabolism in fish. PLoS ONE 2012, 7, e32254. [CrossRef]

43. Besseling, E.; Wang, B.; Lurling, M.; Koelmans, A.A. Nanoplastic Affects Growth of S. Obliquus and Reproduction of D. Magna. Environ. Sci. Technol. 2014, 48, 12336-12343. [CrossRef]

44. Lusher, A.L.; Tirelli, V.; O'Connor, I.; Officer, R. Microplastics in Arctic polar waters: The first reported values of particles in surface and sub-surface samples. Sci. Rep. 2015, 5, 14947. [CrossRef]

45. Ward, J.E.; Shumway, S.E. Separating the grain from the chaff: Particle selection in suspension- and deposit-feeding bivalves. J. Exp. Mar. Biol. Ecol. 2004, 300, 83-130. [CrossRef]

46. Ward, J.E.; Kach, D.J. Marine aggregates facilitate ingestion of nanoparticles by suspension-feeding bivalves. Mar. Environ. Res. 2009, 68, 137-142.

47. El Hadri, H.; Gigault, J.; Maxit, B.; Grassl, B.; Reynaud, S. Nanoplastic from mechanically degraded primary and secondary microplastics for environmental assessments. NanoImpact 2020, 17, 100206. [CrossRef]

48. Pessoni, L.; Veclin, C.; El Hadri, H.; Cugnet, C.; Davranche, M.; Pierson-Wickmann, A.C.; Gigault, J.; Grassl, B.; Reynaud, S. Soapand metal-free polystyrene latex particles as a nanoplastic model. Environ. Sci. Nano 2019, 6, 2253-2258. [CrossRef]

49. Alimi, O.S.; Farner Budarz, J.; Hernandez, L.M.; Tufenkji, N. Microplastics and Nanoplastics in Aquatic Environments: Aggregation, Deposition, and Enhanced Contaminant Transport. Environ. Sci. Technol. 2018, 52, 1704-1724. [CrossRef] [PubMed]

50. Lenz, R.; Enders, K.; Nielsen, T.G. Microplastic exposure studies should be environmentally realistic. Proc. Natl. Acad. Sci. USA 2016, 113, E4121-E4122. [CrossRef] 
51. Besseling, E.; Quik, J.T.K.; Sun, M.; Koelmans, A.A. Fate of nano- and microplastic in freshwater systems: A modeling study. Environ. Pollut. 2017, 220, 540-548. [CrossRef] [PubMed]

52. Andrady, A.L.; Neal, M.A. Applications and societal benefits of plastics. Philos. Trans. R. Soc. Lond. 2009, 364, 1977-1984. [CrossRef]

53. Marie, V.; Gonzalez, P.; Baudrimont, M.; Boutet, I.; Moraga, D.; Bourdineaud, J.P.; Boudou, A. Metallothionein gene expression and protein levels in triploid and diploid oysters Crassostrea gigas after exposure to cadmium and zinc. Environ. Toxicol. Chem. 2006, 25, 412-418. [CrossRef] [PubMed]

54. Strady, E.; Schäfer, J.; Baudrimont, M.; Blanc, G. Tracing cadmium contamination kinetics and pathways in oysters (Crassostrea gigas) by multiple stable Cd isotope spike experiments. Ecotoxicol. Environ. Saf. 2011, 74, 600-606. [CrossRef]

55. Gonzalez Araya, R.; Mingant, C.; Petton, B.; Robert, R. Influence of diet assemblage on Ostrea edulis broodstock conditioning and subsequent larval development. Aquaculture 2012, 364-365, 272-280. [CrossRef]

56. Helm, M.M.; Bourne, N. Hatchery Culture of Bivalves. A Practical Manual; FAO Fisheries Technical Paper 471; FAO: Rome, Italy, 2004; p. 177.

57. Saed, K.; Ismail, A.; Omar, H.; Kusnan, M. Heavy metal depuration in flat tree oysters Isognomon alatus under field and laboratory conditions. Toxicol. Environ. Chem. 2004, 86, 171-179. [CrossRef]

58. Yap, C.K.; Azmizan, A.R.; Hanif, M.S. Biomonitoring of Trace Metals (Fe, Cu, and Ni) in the Mangrove Area of Peninsular Malaysia Using Different Soft Tissues of Flat Tree Oyster Isognomon alatus. Water Air Soil Pollut. 2011, 218, 19-36. [CrossRef]

59. Penrose, W.R. Arsenic in the marine and aquatic environments: Analysis, occurrence and significance. CRC Crit. Rev. Environ. Control 1974, 4, 465-482. [CrossRef]

60. Neff, J.M. Ecotoxicology of arsenic in the marine environment. Environ. Toxicol. Chem. 1997, 16, 917-927.

61. Yang, H.C.; Fu, H.L.; Lin, Y.F.; Rosen, B.P. Pathways of Arsenic Uptake and Efflux. Curr. Top. Membr. 2012, 69, 325-358.

62. Zhang, W.; Wang, W.-X.; Zhang, L. Arsenic speciation and spatial and interspecies differences of metal concentrations in mollusks and crustaceans from a South China estuary. Ecotoxicology 2013, 22, 671-682. [CrossRef]

63. Langston, W.J. Availability of arsenic to estuarine and marine organisms: A field and laboratory evaluation. Mar. Biol. 1984, 80, 143-154. [CrossRef]

64. Zhang, W.; Guo, Z.; Zhou, Y.; Liu, H.; Zhang, L. Biotransformation and detoxification of inorganic arsenic in Bombay oyster Saccostrea cucullata. Aquat. Toxicol. 2015, 158, 33-40. [CrossRef] [PubMed]

65. Freitas, R.; Coppola, F.; De Marchi, L.; Codella, V.; Pretti, C.; Chiellini, F.; Morelli, A.; Polese, G.; Soares, A.M.V.M.; Figueira, E. The influence of Arsenic on the toxicity of carbon nanoparticles in bivalves. J. Hazard. Mater. 2018, 358, 484-493. [CrossRef]

66. Malet, N.; Sauriau, P.G.; Ryckaert, M.; Malestroit, P.; Guillou, G. Dynamics and sources of suspended particulate organic matter in the Marennes-Oléron oyster farming bay: Insights from stable isotopes and microalgae ecology. Estuar. Coast. Shelf Sci. 2008, 78, 576-586. [CrossRef]

67. Lucas, A.; Beninger, P.G. The use of physiological condition indices in marine bivalve aquaculture. Aquaculture 1985, 4, 187-200.

68. Yang, L.; Willie, S.; Grinberg, P.; Pihillagawa Gedara, I.; Clancy, V.; Maxwell, P.; McRae, G.; Meija, J.; Mester, Z. DOLT-5: Dogfish Liver Certified Reference Material for Trace Metals and Other Constituents; National Research Council Canada: Ottawa, ON, Canada, 2014.

69. Vicient, C.M.; Delseny, M. Isolation of Total RNA from Arabidopsis thaliana Seeds. Anal. Biochem. 1999, 268, 412-413. [CrossRef]

70. Lemer, S. Assembled and Translated Transcriptomes; Harvard Dataverse. 2019. Available online: https://dataverse.harvard.edu/ dataset.xhtml?persistentId=doi:10.7910/DVN/NBJBQP (accessed on 27 April 2013).

71. Conner, S.D.; Schmid, S.L. Regulated portals of entry into the cell. Nature 2003, 422, 37-44. [CrossRef] [PubMed]

72. Doherty, G.J.; McMahon, H.T. Mechanisms of endocytosis. Annu. Rev. Biochem. 2009, 78, 857-902. [CrossRef]

73. Harris, S.; Levine, A. The $p 53$ pathway: Positive and negative feedback loops. Oncogene 2005, 24, $2899-2908$.

74. Salvador, J.M.; Brown-Clay, J.D.; Fornace, A.J. gadd45 in Stress Signaling, Cell Cycle Control, and Apoptosis. Exp. Med. Biol. 2013, 793, 1-19.

75. Defo, M.A.; Bernatchez, L.; Campbell, P.G.C.; Couture, P. Temporal variations in kidney metal concentrations and their implications for retinoid metabolism and oxidative stress response in wild yellow perch (Perca flavescens). Aquat. Toxicol. 2018, 202, 26-35. [CrossRef]

76. Tristan, C.; Shahani, N.; Sedlak, T.W.; Sawa, A. The diverse functions of gapdh: Views from different subcellular compartments. Cell. Signal. 2011, 23, 317-323. [CrossRef]

77. Sirover, M.A. On the functional diversity of glyceraldehyde-3-phosphate dehydrogenase: Biochemical mechanisms and regulatory control. Biochim. Biophys. Acta Gen. Subj. 2011, 1810, 741-751. [CrossRef]

78. Al Kaddissi, S.; Legeay, A.; Elia, A.C.; Gonzalez, P.; Floriani, M.; Cavalie, I.; Massabuau, J.-C.; Gilbin, R.; Simon, O. Mitochondrial gene expression, antioxidant responses, and histopathology after cadmium exposure. Environ. Toxicol. 2012, 29, 893-907. [CrossRef] [PubMed]

79. Arini, A.; Gourves, P.-Y.; Gonzalez, P.; Baudrimont, M. Metal detoxification and gene expression regulation after a Cd and Zn contamination: An experimental study on Danio Rerio. Chemosphere 2015, 128, 125-133. [CrossRef] [PubMed]

80. Franzellitti, S.; Fabbri, E. Cytoprotective responses in the Mediterranean mussel exposed to $\mathrm{Hg}^{2+} \mathrm{and}_{\mathrm{CH}} \mathrm{Hg}^{+}$. Biochem. Biophys. Res. Commun. 2006, 351, 719-725. [CrossRef] 
81. Livak, K.J.; Schmittgen, T.D. Analysis of relative gene expression data using real-time quantitative PCR and the $2^{-\Delta \Delta C T}$ method. Methods 2001, 25, 402-408. [CrossRef] [PubMed]

82. Lee, S.Y.; Nam, Y.K. Evaluation of reference genes for RT-qPCR study in abalone Haliotis discus hannai during heavy metal overload stress. Fish. Aquat. Sci. 2016, 19, 21. [CrossRef]

83. Maher, W.; Waring, J.; Krikowa, F.; Duncan, E.; Foster, S. Ecological factors affecting the accumulation and speciation of arsenic in twelve Australian coastal bivalve molluscs. Environ. Chem. 2018, 15, 46. [CrossRef]

84. Soegianto, A.; Winarni, D.; Handayani, U.S.; Hartati. Bioaccumulation, Elimination, and Toxic Effect of Cadmium on Structure of Gills and Hepatopancreas of Freshwater Prawn Macrobrachium sintangese (De Man, 1898). Water Air Soil Pollut. 2013, $224,1575$. [CrossRef]

85. Arini, A.; Daffe, G.; Gonzalez, P.; Feurtet-Mazel, A.; Baudrimont, M. Detoxification and recovery capacities of Corbicula fluminea after an industrial metal contamination (Cd and $\mathrm{Zn}$ ): A one-year depuration experiment. Environ. Pollut. 2014, 192, 74-82. [CrossRef]

86. Perrier, F. Nano Contamination D'Organismes Aquatiques par des Particules Inorganiques: Transfert Trophique et Impacts Toxiques. Ph.D. Thesis, Université de Bordeaux, Bordeaux, France, 2017.

87. Francesconi, K.A.; Edmonds, J.S. Arsenic and Marine Organisms. Adv. Inorg. Chem. 1996, 44, 147-189.

88. Farrell, A.P.; Brauner, C.J.; Wood, C.M. Fish Physiology: Homeostasis and Toxicology of Essential Metals. Fish Physiol. 2012, 31, 300-301.

89. Rahman, M.A.; Hasegawa, H.; Lim, R.P. Bioaccumulation, biotransformation and trophic transfer of arsenic in the aquatic food chain. Environ. Res. 2012, 116, 118-135. [CrossRef]

90. Ünlü, M.Y.; Fowler, S.W. Factors affecting the flux of arsenic through the mussel Mytilus galloprovincialis. Mar. Biol. 1979, 51, 209-219. [CrossRef]

91. Lagarde, F.; Olivier, O.; Zanella, M.; Daniel, P.; Hiard, S.; Caruso, A. Microplastic interactions with freshwater microalgae: Heteroaggregation and changes in plastic density appear strongly dependent on polymer type. Environ. Pollut. 2016, 215, 331-339. [CrossRef]

92. Wang, S.; Liu, M.; Wang, J.; Huang, J.; Wang, J. Polystyrene nanoplastics cause growth inhibition, morphological damage and physiological disturbance in the marine microalga Platymonas Helgol. Mar. Pollut. Bull. 2020, 158, 111403.

93. Green, D.S. Effects of microplastics on European flat oysters, Ostrea edulis and their associated benthic communities. Environ. Pollut. 2016, 216, 95-103. [CrossRef] [PubMed]

94. Lebordais, M.; Manuel Gutierrez-Villagomez, J.; Gigault, J.; Baudrimont, M.; Langlois, V. Molecular impacts of dietary exposure to nanoplastics combined with arsenic in Canadian oysters (Crassostrea virginica) and bioaccumulation comparison with Caribbean oysters (Isognomon alatus). Chemosphere 2021, 277, 130331. [CrossRef]

95. Tedesco, S.; Doyle, H.; Blasco, J.; Redmond, G.; Sheehan, D. Oxidative stress and toxicity of gold nanoparticles in Mytilus edulis. Aquat. Toxicol. 2010, 100, 178-186. [CrossRef] [PubMed]

96. Singh, N.; Manshian, B.; Jenkins, G.J.S.; Griffiths, S.M.; Williams, P.M.; Maffeis, T.G.G.; Wright, C.J.; Doak, S.H. Nanogenotoxicology: The DNA damaging potential of engineered nanomaterials. Biomaterials 2009, 30, 3891-3914. [CrossRef]

97. Ruiz, P.; Katsumiti, A.; Nieto, J.A.; Bori, J.; Jimeno-Romero, A.; Reip, P.; Arostegui, I.; Orbea, A.; Cajaraville, M.P. Short-term effects on antioxidant enzymes and long-term genotoxic and carcinogenic potential of $\mathrm{CuO}$ nanoparticles compared to bulk $\mathrm{CuO}$ and ionic copper in mussels Mytilus Galloprovincialis. Mar. Environ. Res. 2015, 111, 107-120. [CrossRef]

98. Wegner, A.; Besseling, E.; Foekema, E.M.; Kamermans, P.; Koelmans, A.A. Effects of nanopolystyrene on the feeding behavior of the blue mussel (Mytilus edulis). Environ. Toxicol. Chem. 2012, 31, 2490-2497. [CrossRef]

99. Kulkarni, S.A.; Feng, S.S. Effects of Particle Size and Surface Modification on Cellular Uptake and Biodistribution of Polymeric Nanoparticles for Drug Delivery. Pharm. Res. 2013, 30, 2512-2522. [CrossRef]

100. Rosety, M.; Ordóñez, F.J.; Rosety Rodríguez, M.; Rosety, J.M.; Rosety, I.; Carrasco, C.; Ribelles, A. Acute toxicity of anionic surfactants sodium dodecyl sulphate (SDS) and linear alkylbenzene sulphonate (LAS) on the fertilizing capability of gilthead (Sparus aurata L.) sperm. Histol. Histopathol. 2001, 16, 839-843.

101. Hrenovic, J.; Ivankovic, T. Toxicity of anionic and cationic surfactant to Acinetobacter junii in pure culture. Open Life Sci. 2007, 2, 405-414. [CrossRef]

102. Jahan, K.; Balzer, S.; Mosto, P. Toxicity of Nonionic Surfactants. WIT Trans. Ecol. Environ. 2008, 110, $281-290$.

103. Pikuda, O.; Xu, E.G.; Berk, D.; Tufenkji, N. Toxicity Assessments of Micro- and Nanoplastics Can Be Confounded by Preservatives in Commercial Formulations. Environ. Sci. Technol. Lett. 2018, 6, 21-25. [CrossRef]

104. Cai, L.; Hu, L.; Shi, H.; Ye, J.; Zhang, Y.; Kim, H. Effects of inorganic ions and natural organic matter on the aggregation of nanoplastics. Chemosphere 2018, 197, 142-151. [CrossRef] [PubMed]

105. Beyersmann, D. Effects of carcinogenic metals on gene expression. Toxicol. Lett. 2002, 127, 63-68. [CrossRef]

106. Minier, C.; Borghi, V.; Moore, M.N.; Porte, C. Seasonal variation of MXR and stress proteins in the common mussel, Mytilus galloprovincialis. Aquat. Toxicol. 2000, 50, 167-176. [CrossRef]

107. El Haj, Y.; Bohn, S.; Souza, M.M. Tolerance of native and invasive bivalves under herbicide and metal contamination: An ex vivo approach. Environ. Sci. Pollut. Res. 2019, 26, 31198-31206.

108. Holmes, L.A.; Turner, A.; Thompson, R. Interactions between trace metals and plastic production pellets under estuarine conditions. Mar. Chem. 2014, 167, 25-32. [CrossRef] 
109. Dawson, A.L.; Kawaguchi, S.; King, C.K.; Townsend, K.A.; King, R.; Huston, W.M.; Bengtson Nash, S.M. Turning microplastics into nanoplastics through digestive fragmentation by Antarctic krill. Nat. Commun. 2018, 9, 1-8. [CrossRef]

110. Tran, D.; Ciret, P.; Ciutat, A.; Durrieu, G.; Massabuau, J.C. Estimation of potential and limits of bivalve closure response to detect contaminants: Application to cadmium. Environ. Toxicol. Chem. 2003, 22, 914-920. [CrossRef]

111. Pan, K.; Wang, W.-X. Reconstructing the Biokinetic Processes of Oysters to Counteract the Metal Challenges: Physiological Acclimation. Environ. Sci. Technol. 2012, 46, 10765-10771. [CrossRef] [PubMed]

112. Oliveira, P.; Barboza, L.G.A.; Branco, V.; Figueiredo, N.; Carvalho, C.; Guilhermino, L. Effects of microplastics and mercury in the freshwater bivalve Corbicula fluminea (Müller, 1774): Filtration rate, biochemical biomarkers and mercury bioconcentration. Ecotoxicol. Environ. Saf. 2018, 164, 155-163. [CrossRef] [PubMed]

113. Wen, B.; Jin, S.-R.; Chen, Z.-Z.; Gao, J.-Z.; Liu, Y.-N.; Liu, J.-H.; Feng, X.S. Single and combined effects of microplastics and cadmium on the cadmium accumulation, antioxidant defence and innate immunity of the discus fish (Symphysodon aequifasciatus). Environ. Pollut. 2018, 243, 462-471. [CrossRef] [PubMed]

114. Bhagat, J.; Nishimura, N.; Shimada, Y. Toxicological interactions of microplastics/nanoplastics and environmental contaminants: Current Knowledge and Future Perspectives. J. Hazard. Mater. 2020, 405, 123913. [CrossRef] 